\title{
Voltammetry of Mercury(II) Based on an Organo-Clay Modified Graphite Electrode
}

\author{
Newton L. Dias Filho, ${ }^{1, *}$ Giovana L. Okajima ${ }^{1}$, Geovanna Pires ${ }^{1}$, Reginaldo \\ M. Costa ${ }^{1}$, Devaney R. do Carmo ${ }^{1}$, André H. Rosa ${ }^{2}$ \\ ${ }^{I}$ Departamento de Física e Química, Unesp-Universidade Estadual Paulista, Av. Brasil, 56- \\ Centro, C. P. 31, 15385-000 Ilha Solteira- SP, Brazil \\ ${ }^{2}$ Departamento de Engenharia Ambiental, Unesp-Universidade Estadual Paulista, \\ CEP 18087-180, Sorocaba, SP - Brazil
}

Received 21 November 2006; accepted 15 February 2008

\begin{abstract}
Organo-clay complex of ligand-hexadecyltrimethylammonium with montmorillonite was made for the purpose of application as a preconcentration agent in a chemically modified carbon paste electrode for determination of mercury (II) in aqueous solution. It was found out that the adsorption of $\mathrm{Hg}$ (II) by organo-clay complex is independent of the $\mathrm{pH}$ of the solution. It was also found out that the adsorption of the remaining metals $\mathrm{Cd}(\mathrm{II}), \mathrm{Pb}(\mathrm{II}), \mathrm{Cu}(\mathrm{II}), \mathrm{Zn}$ (II), and $\mathrm{Ni}$ (II) was dependent on the changes in $\mathrm{pH}$ solutions and increased when it varies from 1 to 8 . The resultant material was characterized by cyclic and differential pulse anodic voltammetry using a modified graphite paste electrode in different supporting electrolytes. The mercury response was evaluated with respect to $\mathrm{pH}$, electrode composition, preconcentration time, mercury concentration, possible interferences and other variables.
\end{abstract}

Keywords: adsorption, preconcentration, clay, carbon paste electrode, voltammetry.

\section{Introduction}

In recent years there has been an increased interest in natural materials likely to be of use in purifying industrial wastes polluted by heavy metals [1-11]. The exchangeable cations present on montmorillonites can be replaced by long-chain quaternary ammonium cations, the resulting clays having some useful properties, e.g., they are able to adsorb organic molecules.

\footnotetext{
* Corresponding author. E-mail address: nldias@msn.com (N. L.Dias Filho)
} 
Clays modified by adsorption of ionic surfactants enhance their sorption capacity and selectivity for a variety of organic molecules. Increasing the surfactant concentration, an increase in the organic molecule aggregation on the clay is observed, followed by a migration of the organic molecules to the internal domains of the clay particles [6-11].

Clay modified electrodes have potential use in electrocatalysis and they are very promising as sensors in electroanalytical chemistry [12-22]. The typical examples include the preparation of organosilasesquioxane-laponite clay films on solid electrodes and their subsequent utilization as electrochemical biosensors [23-24]. However, application of 2-mercapto-5-amino-1,3,4-thiadiazolehexadecyltrime-thylammonium bromide-montmorillonite complex as a preconcentration agent in a chemically modified carbon paste electrode for determination of mercury (II) in aqueous solution has not yet been explored.

The speciation of mercury at trace levels in environmental samples is of great importance nowadays because mercury is one of the most important contaminants in water and accumulative metals in biological systems [25].

The objective of this work was to place an ionic surfactant and a ligand (organic base) within the interlamellar spaces of layer lattice silicates, such as montmorillonite, for the purpose of adsorption of heavy metal ions in aqueous medium, as well as for the application in voltammetric determination of mercury at a chemically modified carbon-paste electrode.

\section{Experimental}

\section{Chemicals and reagents}

All chemicals were of analytical reagent grade unless stated otherwise. The surfactant used in the preparation of the organo-clay was the commercial product hexadecyltrimethylammonium (HDTA) bromide (purum quality). Solutions were prepared from doubly-demineralized water (conductivity of $18.2 \mathrm{M} \Omega-\mathrm{cm}$ ) obtained by passing distilled water through a Millipore Milli-Q water purification system. Dilute solutions ( $\leq 1 \times 10^{-3} \mathrm{~mol} \mathrm{~L}^{-1}$ ) of $\mathrm{Hg}(\mathrm{II})$ and other ions were prepared fresh daily. Stock standard solutions of $\mathrm{Hg}(\mathrm{II}), \mathrm{Pb}(\mathrm{II}), \mathrm{Cd}(\mathrm{II}), \mathrm{Cu}(\mathrm{II})$, and $\mathrm{Zn}(\mathrm{II})$ and other ions were prepared by stepwise dilution from $1000 \mathrm{mg} \mathrm{L}^{-1}$ Titrisol standards (Merck).

\section{Preparation of the organo-clay complex}

The clay used in this work was a sample of montmorillonite (Volclay 325) from Wyoming, USA, supplied by American Colloid Company, Arlington Heights, IL, USA. Clay mineral montmorillonite was converted into the sodium homoionic form, Na-montmorillonite, by the procedure described in the literature [26].

The sodium form of the clay, homoionic Na-montmorillonite, was treated with an aqueous solution containing an excess of the hexadecyltrimethylammonium (HDTA) bromide salt, with the formulae of $\left[\left(\mathrm{CH}_{3}\right)_{3} \mathrm{~N}\left(\mathrm{C}_{16} \mathrm{H}_{33}\right)\right]^{+}$, then washed with distilled water until no free bromide was found. The homoionic hexadecyltrimethylammonium-clay (HDTA-montmorillonite) was then dialyzed to remove excess salt, freeze-dried, and stored at room temperature. 
Based on the fact that usual organo-clays have high affinities for nonionic organic molecules, 2-mercapto-5-amino-1,3,4-thiadiazole (MAT) was loaded on the HDTA-montmorillonite surface, by the usual procedure [6-10] described as follows.

About $50 \mathrm{~g}$ of HDTA-montmorillonite were immersed in $50 \mathrm{~mL}$ of MAT pyridine solution $(10 \mathrm{w} / \mathrm{v} \%)$ and shaken continuously at room temperature. After $72 \mathrm{~h}$ the solution was removed, and the solid was washed several times with deionized water, re-dispersed in a fresh MAT pyridine solution, and allowed to react again for $72 \mathrm{~h}$ at $70{ }^{\circ} \mathrm{C}$. Then, the solvent was removed in a rotary evaporator under vacuum. The product obtained, 2-mercapto-5-amino-1,3,4thiadiazole-HDTA-montmorillonite complex, hereafter denominated as MATorgano-clay, was suspended in deionized water with continuous stirring for $8 \mathrm{~h}$, then filtered and washed with deionized water. The material was again washed repeatedly with deionized water to remove any non-adsorbed reagent and dialysed at $70{ }^{\circ} \mathrm{C}$ until de $\mathrm{C} / \mathrm{N}$ content was virtually constant. Finally, the product was dried at $353 \mathrm{~K}$ under reduced pressure for about $8 \mathrm{~h}$.

\section{Adsorption isotherms and preconcentration experiments}

The adsorption isotherms of metal ions by MAT-organo-clay were determined for $\mathrm{Hg}(\mathrm{II}), \mathrm{Cd}(\mathrm{II}), \mathrm{Pb}(\mathrm{II}), \mathrm{Cu}(\mathrm{II}), \mathrm{Zn}(\mathrm{II})$, and $\mathrm{Ni}(\mathrm{II})$ metal ions in aqueous solutions at different $\mathrm{pH}$ values by batch method. About $0.5 \mathrm{~g}$ of the sorbent were immersed in $50 \mathrm{~mL}$ solution of metal ions of $2.5 \times 10^{-3} \mathrm{~mol} \mathrm{~L}^{-1}$ and shaken for $30 \mathrm{~min}$ at $298 \pm 0.2 \mathrm{~K}$. The quantity of the metal in each flask was determined by AAS.

The quantity of the adsorbed metal, $\mathrm{N}_{\mathrm{f}}$, in each flask was determined by Equation 1:

$$
\mathrm{N}_{\mathrm{f}}=\left(\mathrm{N}_{\mathrm{a}}-\mathrm{N}_{\mathrm{s}}\right) / \mathrm{m}
$$

where $\mathrm{N}_{\mathrm{a}}$ is the initial mole number of the metal in the solution phase, $\mathrm{N}_{\mathrm{s}}$ is the metal mole number under equilibrium condition, and $\mathrm{m}$ is the mass of the adsorbent.

For the preconcentration of individual metal ions by column method, each metal was quantitatively adsorbed adjusting the $\mathrm{pH}$ solutions according to the values found in the previous batch method. For these experiments, a glass column with $20 \times 0.8 \mathrm{~cm}$ i.d. was packed with about $5 \mathrm{~g}$ of the sorbent. Initially the column was washed with pure water and then $1000 \mathrm{~mL}$ of solution of metal ion of $0.5 \mathrm{x}$ $10^{-6} \mathrm{~mol} \mathrm{~L}^{-1}$ were percolated through the column with a flow rate of $5.0 \mathrm{~mL}$ $\min ^{-1}$. In every run, the effluent was collected and a quantity of metal ion analysed. Elution of the metals from the column was made by passing $25 \mathrm{~mL}$ of hydrochloric or nitric acid of different concentrations. Quantitative elution of $\mathrm{Hg}$ (II) was also possible passing $25 \mathrm{~mL}$ of $0.10 \mathrm{~mol} \mathrm{~L}^{-1}$ cysteine solution acidified with $1.0 \mathrm{~mol} \mathrm{~L}{ }^{-1} \mathrm{HCl}$ solution.

Adsorption and elution studies of a mixture of the metal ions $\mathrm{Hg}(\mathrm{II}), \mathrm{Cd}(\mathrm{II})$, $\mathrm{Pb}(\mathrm{II}), \mathrm{Cu}$ (II), and $\mathrm{Zn}$ (II) as well interference of other metal ions, such as $\mathrm{Co}(\mathrm{II})$, $\mathrm{Ni}(\mathrm{II}), \mathrm{Mn}(\mathrm{II}), \mathrm{Bi}(\mathrm{III}), \mathrm{Fe}(\mathrm{II})$ and $\mathrm{Fe}(\mathrm{III})$ were also carried out. The interference of some anions, such as chloride, nitrate, sulphate, fluoride, thiocyanate, 
bromide, phosphate, acetate, oxalate, and tartrate has also been investigated in this work. In these studies, a series of aqueous solutions was prepared in which the metal ion concentrations were fixed at $0.25 \times 10^{-6} \mathrm{~mol} \mathrm{~L}^{-1}$, except for one of them fixed at $2.5 \times 10^{-6}$ or $25.0 \times 10^{-6} \mathrm{~mol} \mathrm{~L}^{-1}$. For adsorption, $1000 \mathrm{~mL}$ of aqueous elution was percolated through the column. The adsorbed metal ions were eluted using solutions previously known from study of preconcentration of individual metal ions.

\section{Apparatus}

The $\mathrm{N}$ content of the samples was determined by elemental analysis using an equipment EA 1110 from CE Instruments. The data reported are average of at least three parallel determinations. The basal spacings $d_{L}$ of the clay samples were measured by X-ray diffraction using a Philips X-ray diffractometer Model XRG 3100, with a tube of $\mathrm{Cu} \lambda \mathrm{k} \alpha 1.5406 \AA, 40 \mathrm{kV} / 20 \mathrm{~mA}$. The specific surface area was obtainde by the BET technique using ASAP 2000 Micromeritics apparatus.

All electrochemical measurements were recorded with an EG \& G Princeton Applied Research Model 273A polarographic analyzer connected to a microcomputer for data collecting. The electrochemical behaviour of MATorgano-clay-CPE was monitored by cyclic voltammetry and differential pulse anodic stripping voltammetry (DPASV). A three-electrode cell involving a MAT-organo-clay carbon paste as the working electrode, a $\mathrm{KCl}$ saturated $\mathrm{Ag} / \mathrm{AgCl}$, as the reference electrode, and a Pt-wire as the auxiliary electrode was used for all investigations

\section{Preparation of the MAT-organo-clay-CPE}

The chemically modified carbon paste electrode, hereafter designated as MATorgano-clay-CPE, was prepared by mixing $20 \mathrm{mg}$ of MAT-organo-clay with 80 mg of graphite (Aldrich) and $50 \mu \mathrm{L}$ of mineral oil. The MAT-organo-clay-CPE was introduced into the glass cavity with $2 \mathrm{~mm}$ inner diameter, connected with of copper wire.

\section{Procedure}

\section{Electrode conditioning}

Fresh MAT-organo-clay-CPE surfaces were conditioned by exposure to a $1.0 \mathrm{mg}$ $\mathrm{L}^{-1}$ mercury solution at $\mathrm{pH} 2.00$, adjusted with $\mathrm{HNO}_{3}$, for 3 min with open circuit. The speed of stirring was $500 \mathrm{rpm}$. The electrode was then rinsed with deionized water. The DPASV was recorded over the range -0.2 to $+0.8 \mathrm{~V}$ in $0.05 \mathrm{~mol} \mathrm{~L}^{-1} \mathrm{KNO}_{3}$ solution. After each measurement, the electrode was rinsed for $2 \mathrm{~min}$ in $0.10 \mathrm{~mol} \mathrm{~L}^{-1}$ cysteine solution acidified with $1.0 \mathrm{~mol} \mathrm{~L}^{-1} \mathrm{HCl}$ solution with open circuit. This conditioning cycle was repeated five times for each new MAT-organo-clay-CPE surface. 


\section{Determination of mercury}

MAT-organo-clay-CPE electrode was placed in $25 \mathrm{~mL}$ of stirred $10^{-6}-10^{-8} \mathrm{~mol}$ $\mathrm{L}^{-1}$ mercury solution for a pre-determined time. The electrode is then removed from the pre-concentration solution, washed with water, dried with absorbent paper and placed in the measurement cell containing $0.05 \mathrm{~mol} \mathrm{~L}^{-1} \mathrm{KNO}_{3}$ solution. Voltammograms were then recorded over the range -0.2 and $+0.8 \mathrm{~V}$. Several "cleaning" solutions were evaluated. Best cleaning efficiency and reproducibility were obtained with $0.10 \mathrm{~mol} \mathrm{~L}^{-1}$ cysteine solution acidified with $1.0 \mathrm{~mol} \mathrm{~L}^{-1} \mathrm{HCl}$ solution. The chosen supporting electrolyte was changed after each measurement and the electrode was cleaned with $0.10 \mathrm{~mol} \mathrm{~L}^{-1}$ cysteine solution acidified with $1.0 \mathrm{~mol} \mathrm{~L}^{-1} \mathrm{HCl}$ solution as in the conditioning step.

\section{Determination of mercury(II) in natural waters}

Successive additions of known concentrations of mercury(II) were introduced into the reference solution of $25 \mathrm{~mL}$ sample of river or sea water. The water samples were collected from the Tiete and Pinheiros River and Ubatuba and Santos beach in São Paulo state (Brazil). The mercury was determined by the DPASV method already described to obtain the dependence between peak heights and the concentration of mercury(II) (calibration plot). Finally, the mercury peaks heights of the spiked water samples were compared with a calibration plot obtained for the reference solution.

\section{Results and discussion}

\section{Properties of the MAT-organo-clay. X-Ray results}

The hydrophilic clay, Na-montmorillonite, was rendered organophilic by exchanging the inorganic interlayer cations for hexadecyltrimethylammonium ions. The total exchange capacity from the $\mathrm{N}(1.05 \%)$ and $\mathrm{C}(17.15 \%)$ content of the alkylammonium derivates is 0.953 and $0.956 \mathrm{mEq} / \mathrm{g}$, respectively. Three decimal digits are given only to reveal the variation in layer charge more clearly. The intensities of the basal reflections of the montmorillonite after alkylammonium ion exchange and swelling are shown in Fig. 1. Displacement of the $\mathrm{Na}^{+}$interlayer cations by HDTA cations increased the intensity of the (001) reflections, and greatly enhanced the structural organization of clay.

The presence of bound long chain hexadecyltrimethylammonium cations, which form a structure between neighbouring lamellae, promotes the accumulation of 2mercapto-5-amino-1,3,4-thiadiazole (MAT) molecules at the solid surface. The amount of MAT loaded on the organo-clay supporting material was $0.235 \mathrm{mmol}$ of MAT per gram of HDTA-clay. The amount of MAT supported on the organoclay was determined by difference between the $\mathrm{N}$ contents of the HDTA-clay and MAT-HDTA-clay (MAT-organo-clay). The specifc surface area was of $230 \mathrm{~m}^{2}$ $\mathrm{g}^{-1}$. The MAT-organo-clay was stable up to $280{ }^{\circ} \mathrm{C}$ and started decomposing above this temperature. 

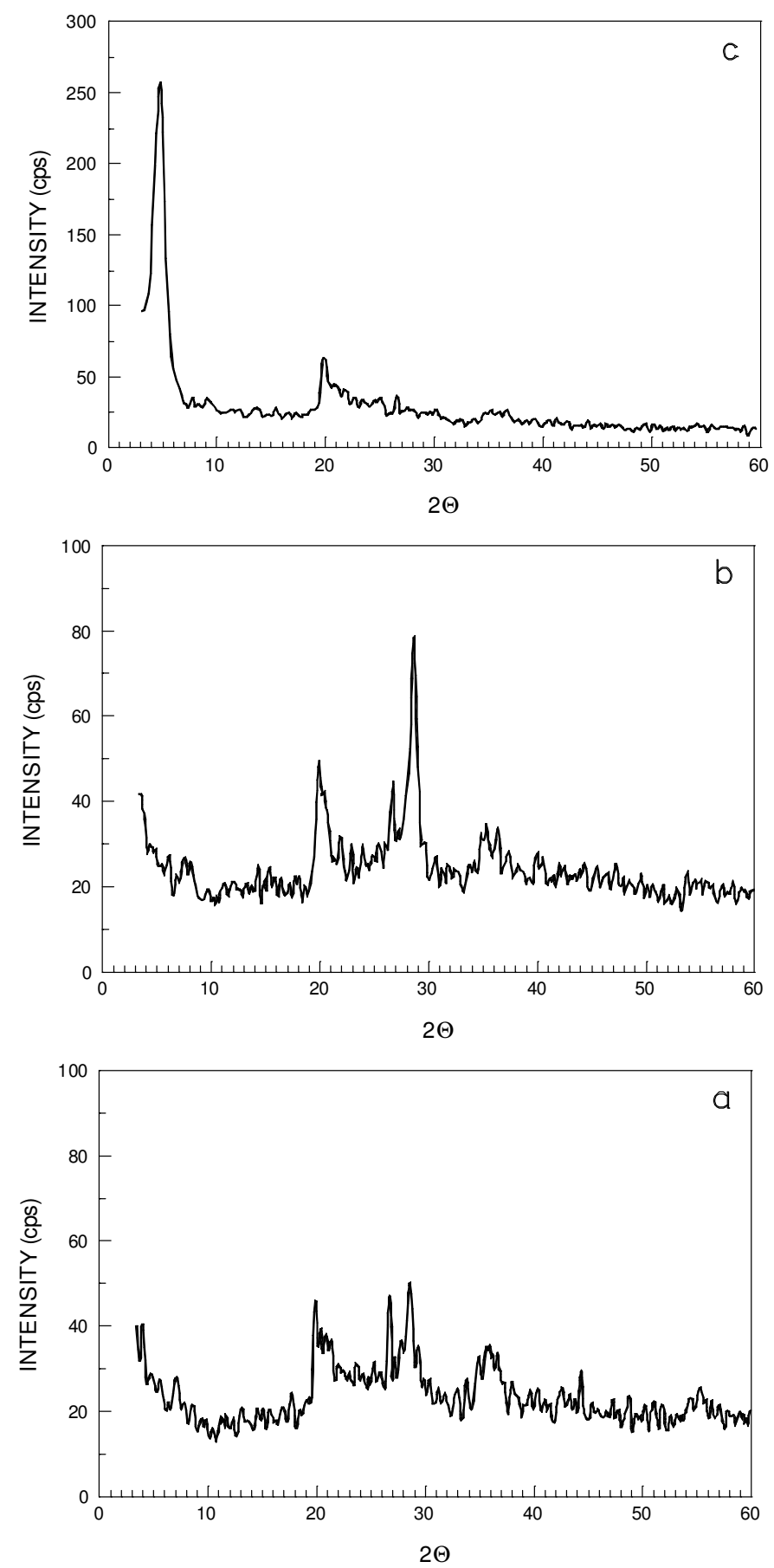

Figure 1. Intensity of the basal reflections after alkylammonium ion exchange and swelling: (a) natural clay; (b) Na-montmorillonite; (c) HDTA-montmorillonite.

\section{Isotherms of adsorption. Preconcentration and recovery of metal ions}

Adsorption of metal ions from solution by a solid phase can occur by formation of a surface complex between the adsorbed ligand and the metal [27-31]. The sorptive capacity is very much increased relative to the same material before loading with the ligand. 
The complexation of mercury at the surface MAT-organo-clay is achieved by direct coordination with the ligand acting possibly as a unidentate towards two metal ions, involving sulphur and/or nitrogen atoms of the MAT molecules loaded on HDTA-clay surface.

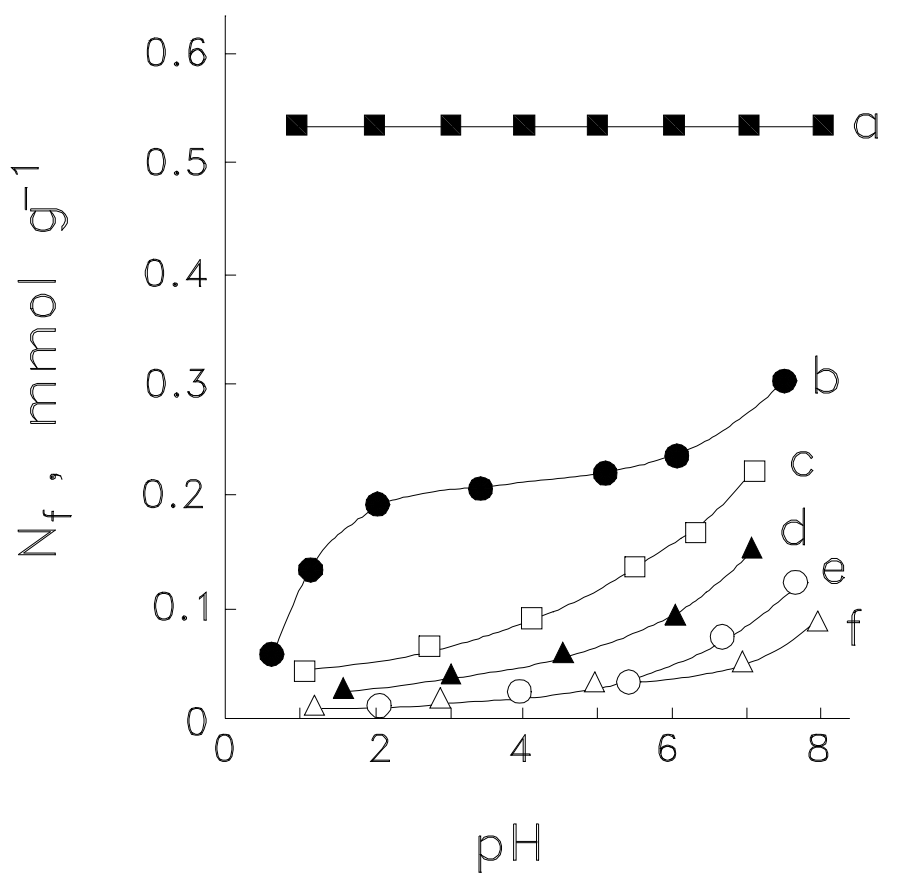

Figure 2. Isotherms of adsorption of metal ions from solutions by MAT-organo-clay as function of $\mathrm{pH}$. (a) $\mathrm{Hg}$ (II), (b) $\mathrm{Cd}$ (II), (c) $\mathrm{Pb}$ (II), (d) $\mathrm{Cu}$ (II), (e) $\mathrm{Zn}$ (II), and (f) $\mathrm{Ni}$ (II).

Isotherms of adsorption of metal ions by MAT-organo-clay from aqueous solutions at different $\mathrm{pH}$ were determined for $\mathrm{Hg}(\mathrm{II}), \mathrm{Cd}(\mathrm{II}), \mathrm{Pb}(\mathrm{II}), \mathrm{Cu}$ (II), $\mathrm{Zn}$ (II), and $\mathrm{Ni}$ (II) metal ions using the batch method. Fixing the initial concentration of metal ion and changing the $\mathrm{pH}$ solutions and plotting $\mathrm{N}_{\mathrm{f}} \mathrm{vs}$. $\mathrm{pH}$, the set of curves shown in Fig. 2 was obtained. Fig. 2 shows that adsorption of $\mathrm{Hg}$ (II) by MAT-organo-clay is independent of the $\mathrm{pH}$ of the solution. Adsorption of the ion by unmodified clay (natural clay and Na-montmorillonite) and HDTAclay is negligible in all the $\mathrm{pH}$ solutions range (isotherms not shown). The high affinity of MAT-organo-clay in all the $\mathrm{pH}$ solutions range by $\mathrm{Hg}(\mathrm{II})$ is well explained by the Pearson rule because MAT and $\mathrm{Hg}$ (II) are soft base and acid, respectively [32]. It can be observed that adsorption of the remaining metals is dependent on changes in $\mathrm{pH}$ solutions and increased when they vary from 1 to 8 .

The fraction of surface-attached ligand bonded to $\mathrm{Hg}(\mathrm{II})$ ion is given by Eq. 2

$$
\varnothing^{\max }=\mathrm{N}_{\mathrm{f}}^{\max } / \mathrm{N}_{\mathrm{o}}
$$

where $\mathrm{N}_{\mathrm{o}}$ is the amount of MAT organofunctional groups (mol) per mass of MAT-organo-clay $(\mathrm{g})$, and $\mathrm{N}_{\mathrm{f}}^{\max }$ is the quantity of the adsorbed metal, $\mathrm{N}_{\mathrm{f}}$, under 
saturation conditions. The value of $\varnothing^{\max }$ for $\mathrm{Hg}(\mathrm{II})$ in all the $\mathrm{pH}$ solutions range is 2,21 . As $\varnothing^{\max } \approx 2$ for $\mathrm{Hg}(\mathrm{II})$, it is clear that this result provides good argument that the complexes formed, presumably, are of the type metal/ligand $=2: 1$. This assumption is reasonably taking into account that the coordination of $\mathrm{Hg}$ (II) to five donor sites of the MAT molecule attached to the matrix is possible. The ligand MAT can act as a unidentate towards two $\mathrm{Hg}$ (II) ions. The coordination can occur simultaneously through nitrogen and sulfur atoms.

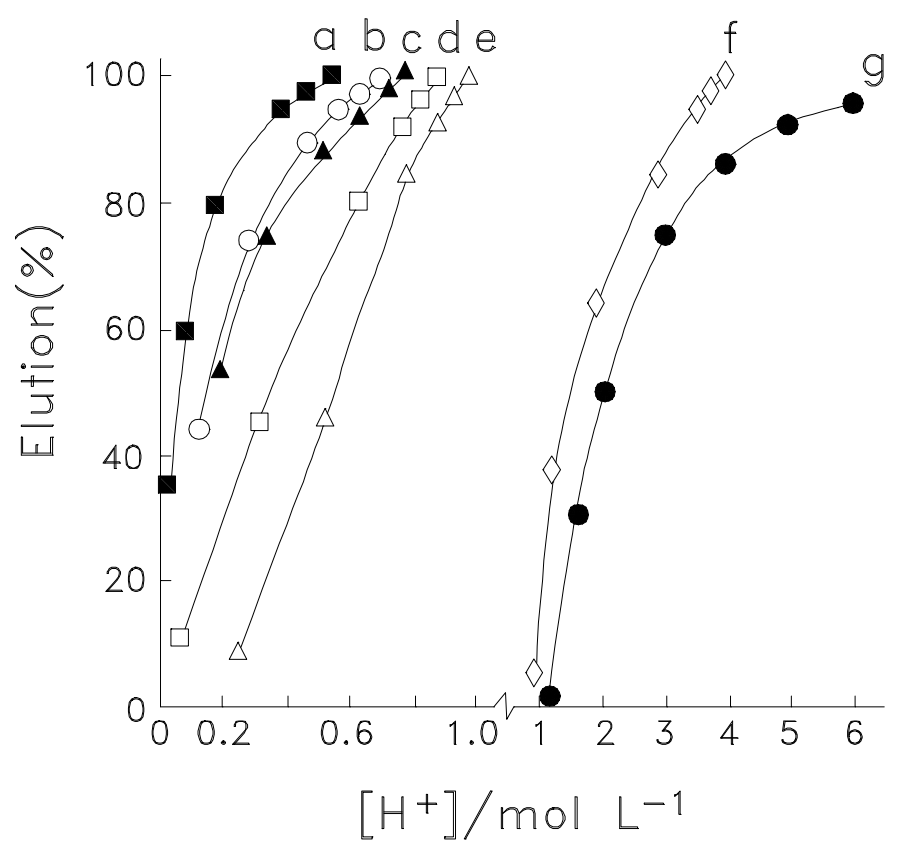

Figure 3. Elution of metal ions adsorbed on MAT-organo-clay by acid solutions. (a) $\mathrm{Ni}(\mathrm{II})$, (b) $\mathrm{Zn}$ (II), (c) $\mathrm{Pb}$ (II), (d) $\mathrm{Cu}$ (II), (e) $\mathrm{Cd}$ (II), (f) $\mathrm{Hg}$ (II) eluted with $\mathrm{HNO}_{3}$, and (g) $\mathrm{Hg}$ (II) eluted with $\mathrm{HCl}$.

Preconcentration of each metal ion by MAT-organo-clay from an aqueous solution was examined by column method. In the experiments, each metal was quantitatively adsorbed and eluted according to Fig. 3. It can be observed that, in the experimental conditions used, only $\mathrm{Cd}(\mathrm{II}), \mathrm{Pb}(\mathrm{II}), \mathrm{Cu}(\mathrm{II}), \mathrm{Zn}$ (II), and $\mathrm{Ni}$ (II) could be quantitatively eluted with until $1.0 \mathrm{M} \mathrm{HCl}$ or $\mathrm{HNO}_{3}$. Mercury forms a strong complex on the surface of the sorbent MAT-organo-clay, and therefore a quantitative desorption is possible by using hydrochloric or nitric acid at a high concentration (4 to $6 \mathrm{M}$ ). Quantitative elution of $\mathrm{Hg}(\mathrm{II})$ was also possible using $25 \mathrm{~mL}$ of $0.10 \mathrm{M}$ solution of cysteine in $1.0 \mathrm{M} \mathrm{HCl}$ (Fig. 4).

In the studies of adsorption and recovery of a mixture of ions, could be observed that recovery of $\mathrm{Hg}(\mathrm{II})$ in the presence of other metal ions, such as $\mathrm{Cd}(\mathrm{II}), \mathrm{Pb}(\mathrm{II})$, $\mathrm{Cu}(\mathrm{II}), \mathrm{Zn}$ (II), $\mathrm{Co}(\mathrm{II}), \mathrm{Ni}(\mathrm{II}), \mathrm{Mn}(\mathrm{II}), \mathrm{Ag}(\mathrm{I}), \mathrm{Bi}(\mathrm{III}), \mathrm{Fe}(\mathrm{II})$ and $\mathrm{Fe}(\mathrm{III})$, in ten or a hundred times higher concentrations, was not significantly affected. These metals are sorbed at higher $\mathrm{pH}$ values, so that a selective preconcentration of $\mathrm{Hg}$ (II) can be carried out in their presence. A 1000-fold excess of chloride, nitrate, sulphate, 
fluoride, thiocyanate, bromide, phosphate, acetate, oxalate, and tartrate ions also does not interfere with the determination.

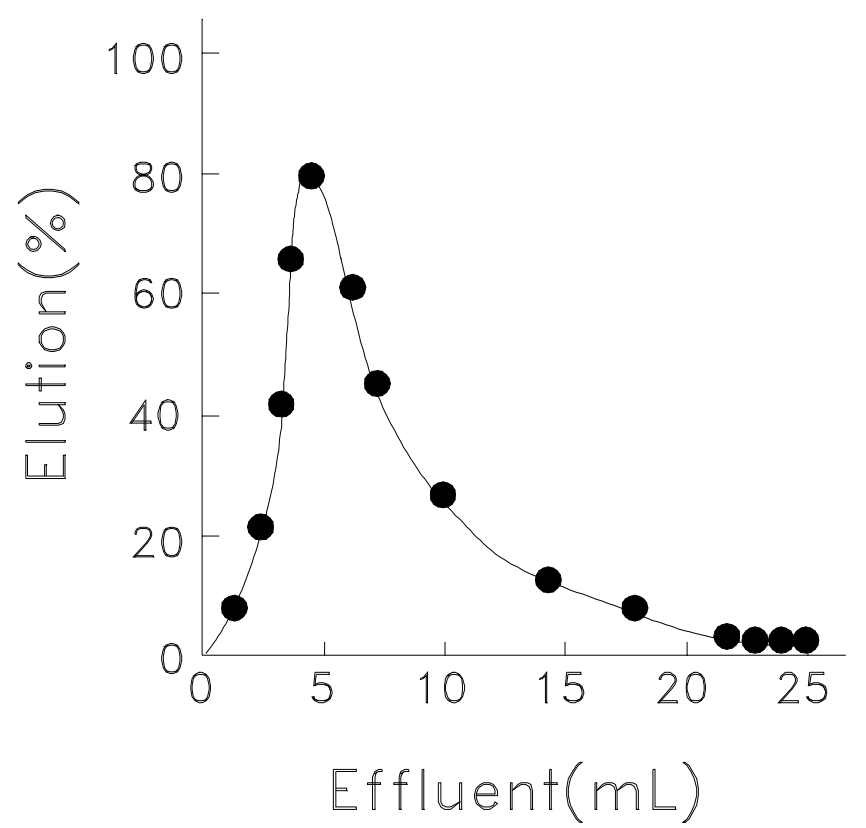

Figure 4. Elution of $\mathrm{Hg}(\mathrm{II})$ adsorbed on MAT-organo-clay by $0.10 \mathrm{M}$ cysteine solution in $1.0 \mathrm{M} \mathrm{HCl}$.

\section{Optimization of experimental conditions for electroanalytical application}

The homoionic hexadecyltrimethylammonium-clay modified by 2-mercapto-5amino-1,3,4-thiadiazole (MAT-organo-clay) was employed as the electrode surface modifier due to the reason that it has shown to be an effective solidphase selective sorbent for $\mathrm{Hg}(\mathrm{II})$. Preconcentration analyses were performed according to the two-step procedure "accumulation at open circuit followed by quantitative voltammetric detection".

In order to establish the most suitable conditions for retention of mercury on the MAT-organo-clay-CPE, several characteristics were examined. Fig. 5 shows a repetitive cyclic voltammogram of mercury(II) solution in the potential range 0.2 to $+0.8 \mathrm{~V}$ vs. $\mathrm{Ag} / \mathrm{AgCl}$, and two peaks were observed. However, the cathodic wave peak, around $0.1 \mathrm{~V}$, is irregular and changes its form in each cycle. This peak at about $0.1 \mathrm{~V}$ is the reduction current for mercury(II) accumulated in the MAT-organo-clay-CPE. The anodic wave peak at $0.375 \mathrm{~V}$ is well defined and does not change during the cycles. This peak is due to the oxidation of the mercury metal. The electrode process is then irreversible and the anodic peak was therefore further investigated for analytical purposes. Since the anodic peak at $0.375 \mathrm{~V}$ is sharp enough to be used for the determination of mercury, the procedure including reduction of the accumulated mercury(II) is recommended. After the accumulation step made with open circuit, the electrode was placed in the electrochemical cell with the supporting electrolyte and a potential of $-0.2 \mathrm{~V}$ 
was applied at the beginning of the scan. When the potential scan reaches the value of $0.375 \mathrm{~V}$, an anodic peak is produced owing the oxidation of mercury as indicates Eq. 3

$$
\mathrm{Hg}^{0} \rightarrow \mathrm{Hg}^{2+}+2 \mathrm{e}^{-}
$$

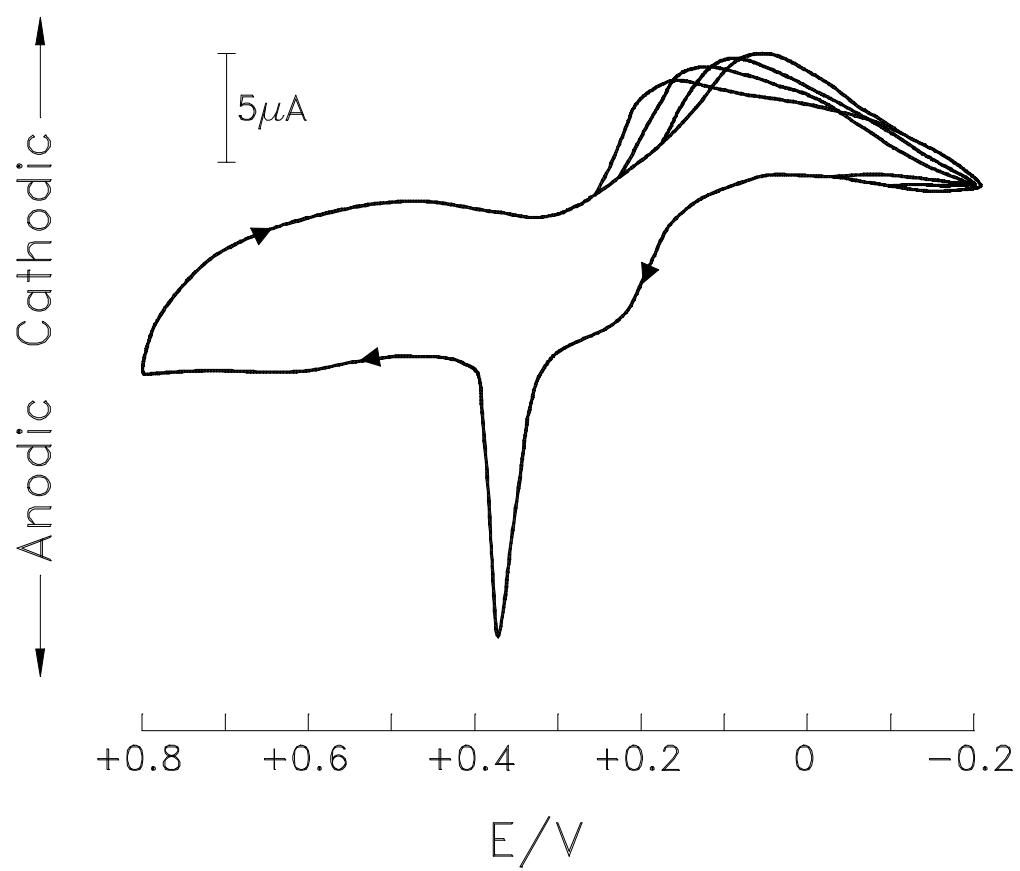

Figure 5. Repetitive cyclic voltammogram of mercury obtained at a carbon paste electrode modified with $20 \%$ (w/w) of MAT-organo-clay. The reference electrode was $\mathrm{KCl}$ saturated $\mathrm{Ag} / \mathrm{AgCl}$, and the auxliliary eletrode was a platinum wire. Suporting electrolyte, $0.05 \mathrm{~mol} \mathrm{~L}^{-1} \mathrm{KNO}_{3}$ solution. Concentration of $\mathrm{Hg}(\mathrm{II}), 0.5 \mathrm{mg} \mathrm{L}^{-1}$. Potential range, -0.2 to $+0.8 \mathrm{~V}$; scan rate $20 \mathrm{mV} \mathrm{s}^{-1}$. Arrows indicate scan direction.

The scan rate of $10 \mathrm{mV} \mathrm{s}^{-1}$ was used in the differential-pulse mode and the scan started immediately after the connection of the electrodes.

For anodic stripping several media were tested, such as $\mathrm{KNO}_{3}, \mathrm{KCl}, \mathrm{KSCN}, \mathrm{KI}$, $\mathrm{KNO}_{2}$, and $\mathrm{KBr}$. The best developed peaks were recorded in $0.05 \mathrm{~mol} \mathrm{~L}^{-1} \mathrm{KNO}_{3}$. This medium allows the reduction and the anodic stripping to be done in a single electrolyte without decreasing the sensitivity and, moreover, the determination may be carried out in the presence of dissolved oxygen. This was confirmed by comparison of results obtained in aerobic and anaerobic media. 


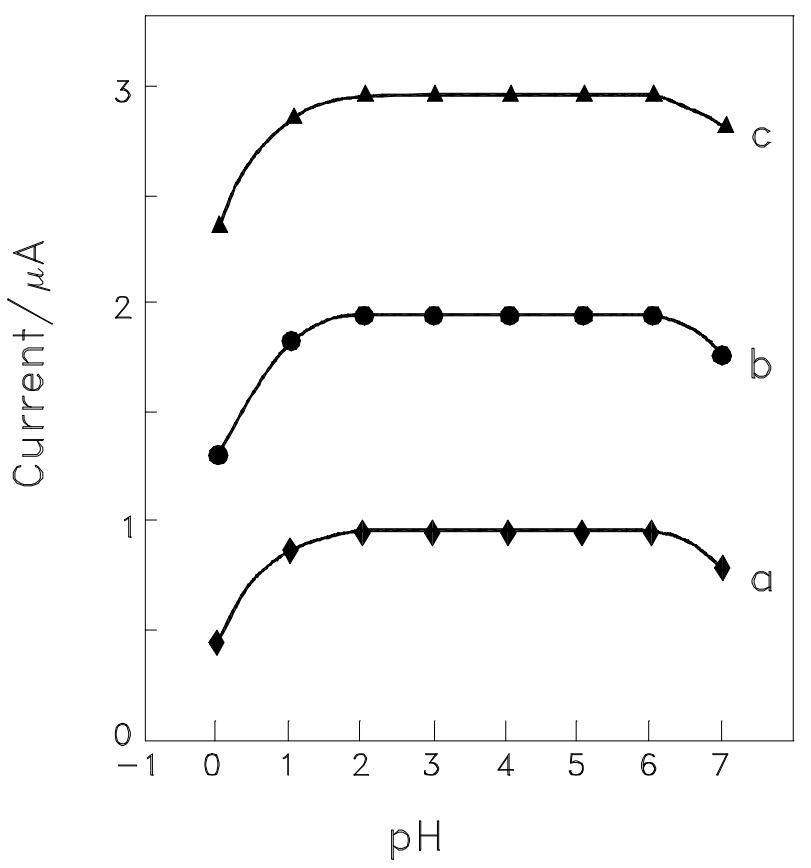

Figure 6. Dependence of the anodic peak current of $\mathrm{Hg}(\mathrm{II})$ on the $\mathrm{pH}$ of the preconcentration solution of $\mathrm{Hg}(\mathrm{II})$. Differential pulse anodic stripping voltammetry with $10 \mathrm{mV} \mathrm{s}^{-1}$ scan rate, $50 \mathrm{mV}$ amplitude and 3 min preconcentration time. $\mathrm{Hg}$ (II) concentration; (a) 0.2 ; (b) 0.4 ; (c) $0.6 \mathrm{mg} \mathrm{L}^{-1}$.

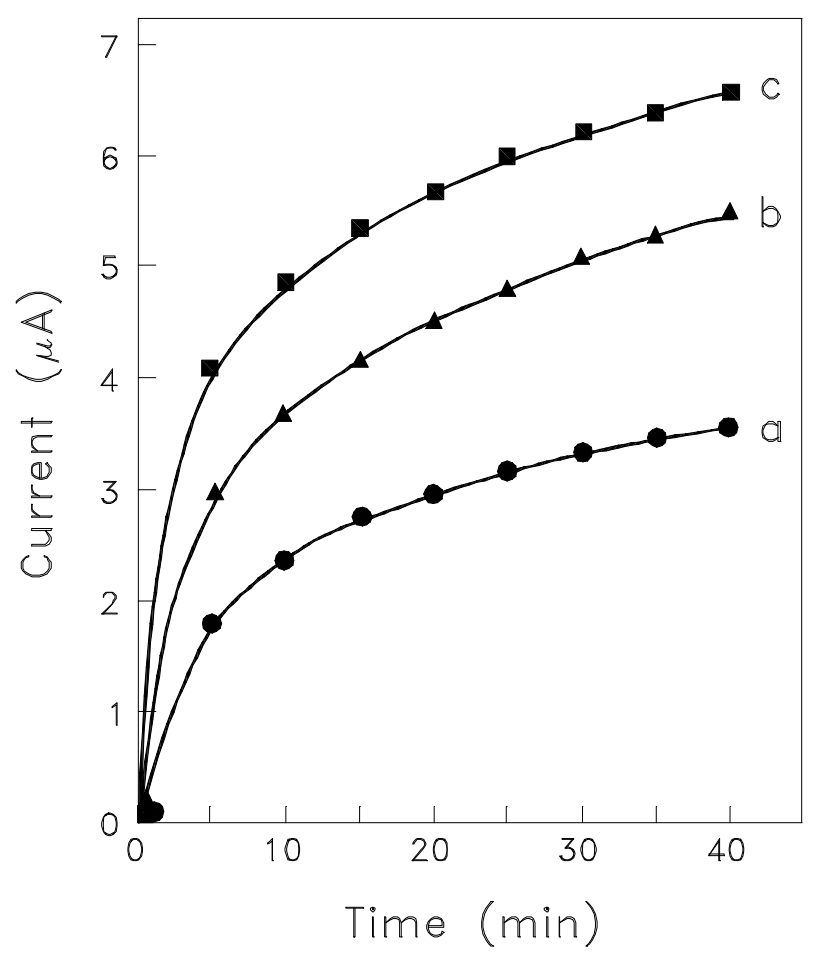

Figure 7. Dependence of the anodic peak current on preconcentration time at different mercury concentrations: (a) 0.2 ; (b) 0.4 ; (c) $0.6 \mathrm{mg} \mathrm{L}^{-1}$.

The influence of the $\mathrm{pH}$ solution on the accumulation of mercury(II) was examined in the concentration range $0.2-0.6 \mathrm{mg} \mathrm{L}^{-1}$. The signal showed a sharp 
increase from $\mathrm{pH} 0.0$ to 2.0 , a stable signal was obtained for the $\mathrm{pH}$ range from 2.0 to 6.0 and then the peak current decreased lightly from $\mathrm{pH} 6.0$ to 7.0 (Fig. $6)$.

The effect of the amount of MAT-organo-clay-CPE on the accumulation of mercury(II) was investigated by altering the weight ratio of MAT-organo-clayCPE to graphite powder in carbon paste. The ratio of MAT-organo-clay-CPE to graphite in the paste was fixed at $20 \%$ (w/w) so that the peak current was constant. A CMCPE with $20 \%$ MAT-organo-clay-CPE was used for most of this work.

Several "cleaning" solutions were evaluated and the best cleaning efficiency and reproducibility were obtained with $0.10 \mathrm{M}$ solution of cysteine in $1.0 \mathrm{M} \mathrm{HCl}$.

A final parameter expected to be of primary importance to the mercury(II) preconcentration was the length of time allowed for the deposition process to take place. The results obtained as a function of accumulation time for three different mercury(II) concentrations are shown in Fig. 7. For each of the three concentrations, the steady-state quantity of mercury(II) deposited was different. Larger signals were obtained for higher concentration, though the dependence was not linear. In all three cases, the greatest increase in current occurred in the first $3 \mathrm{~min}$ and this time was chosen for the preconcentration step. Compared to previously reported rates of uptake of metal ions at various CMCPE surfaces, the present process was very fast [33-40].

\section{Calibration graph, precision, and detection limit}

The calibration graph of current $v s$. mercury concentration in the range $0.01-2$ $\mathrm{mg} \mathrm{L}^{-1}$ in $0.05 \mathrm{~mol} \mathrm{~L}^{-1} \mathrm{KNO}_{3}$ solution for a preconcentration time of $3 \mathrm{~min}$ is shown in Fig. 8. Fig. 9 shows some voltammograms of points on this graph. The calibration graph was linear over the range $0.01-0.7 \mathrm{mg} \mathrm{L}^{-1}$ mercury(II) and obeys the straight-line equation

$$
\mathrm{I}(\mu \mathrm{A})=4.94\left[\mathrm{Hg}^{2+}\right]-0.020
$$

with a correlation coefficient of 0.999 . For points between 0.7 and $2.0 \mathrm{mg} \mathrm{L}^{-1}$, the plot shows non-linear behaviour, which requires the use of a calibration graph in this concentration range.

The reproducible accumulation and effective cleaning was illustrated by the precision obtained for a series of six repetitions $(n=6)$, with 0.03 and $0.09 \mathrm{mg} \mathrm{L}^{-1}$ mercury(II) during a continuous 48 -min period. Such series yielded a relative standard deviation of 4.3 and $3.5 \%$, respectively. The initial preconditioning scheme (described in the experimental section) is essential for achieving such good precision. Reproducible results were obtained with different batches of the same modified carbon paste and MAT-organo-clay-CPE. 


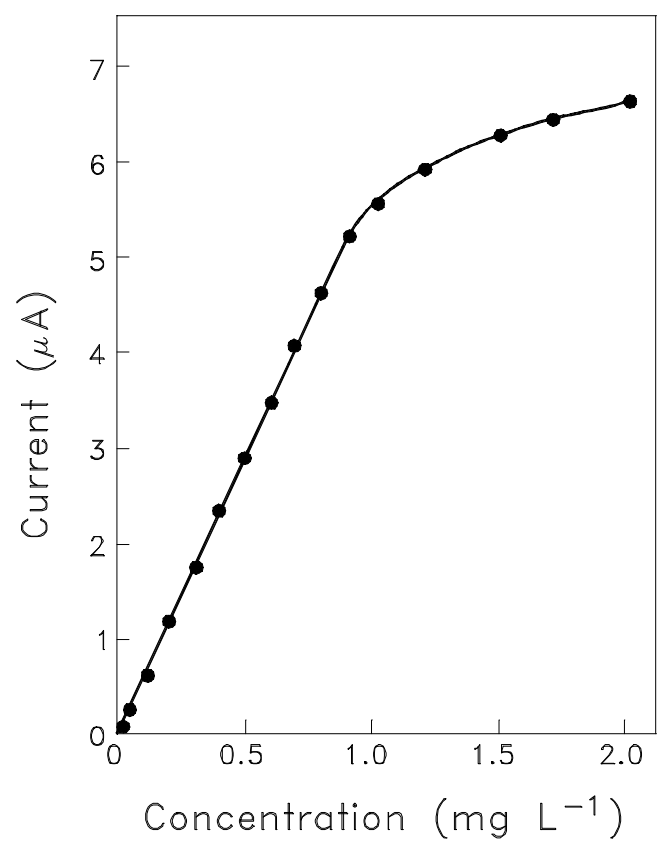

Figure 8. Calibration graph of current versus mercury concentration.

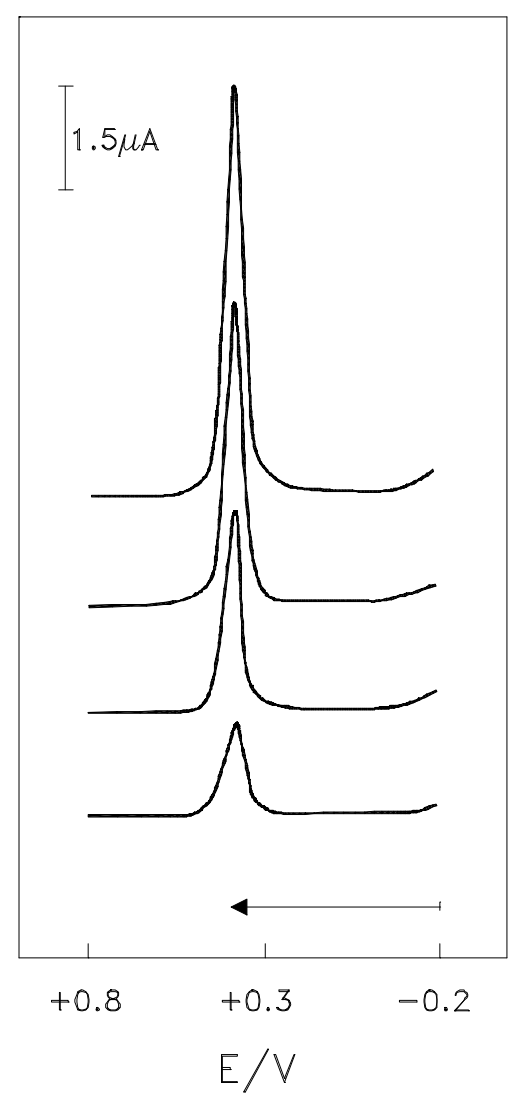

Figure 9. Differential pulse anodic stripping voltammograms for different mercury(II) concentrations obtained after 5-min accumulation: (a) 0.2 ; (b) 0.4 ; (c) 0.6 ; (d) $0.8 \mathrm{mg} \mathrm{L}^{-1}$. 
The detection limit was estimated as $2.0 \mu \mathrm{g} \mathrm{L}^{-1}$ mercury(II) by means of $4: 1$ current-to-noise ratio in connection with the optimization of the various parameters involved and using the highest-possible analyser sensitivity. This detection limit is similar or lower and the concentration range with a linear response is wider than those obtained with other CMCPEs [35-40]. For instance, the detection limits for the determination of $\mathrm{Hg}$ (II) on the carbon paste electrode modified with clay [35], diphenylcarbazone [36], amberlite LA2 [38], and amberlite IRC [39], are $10 \mu \mathrm{g} \mathrm{L} \mathrm{L}^{-1}, 10 \mu \mathrm{g} \mathrm{L} \mathrm{L}^{-1}, 1.0 \mu \mathrm{g} \mathrm{L}^{-1}$, and $25 \mu \mathrm{g} \mathrm{L}^{-1}$, respectively, and for a glassy carbon electrode modified with polypyrrole derivative [40] is $2.0 \mu \mathrm{g} \mathrm{L} \mathrm{L}^{-1}$. As other electrode materials, e.g., $\mathrm{Au}$ and $\mathrm{Pt}$, and other techniques, such as ICP-AES or AAS often in connection with a preconcentration step, are not the subject of this work, they are not considered here.

\section{Influence of foreign ions}

The selectivity of the chemically modified carbon-paste electrode containing MAT-organo-clay was evaluated by intentionally introducing concentrations of other metal ions into $\mathrm{Hg}$ (II) solutions during preconcentration. The ions chosen for study were $\mathrm{Ag}(\mathrm{I}), \mathrm{Zn}(\mathrm{II}), \mathrm{Co}(\mathrm{II}), \mathrm{Pb}(\mathrm{II}), \mathrm{Cu}(\mathrm{II}), \mathrm{Ni}(\mathrm{II}), \mathrm{Mn}(\mathrm{II}), \mathrm{Cd}(\mathrm{II}), \mathrm{Bi}(\mathrm{III})$, $\mathrm{Fe}(\mathrm{II})$ and $\mathrm{Fe}(\mathrm{III})$. These ions were chosen because they might reasonably be expected to exhibit redox activity in roughly the same potential range as $\mathrm{Hg}$ (II)MAT-organo-clay-CPE. The interference of some anions and organic compounds have also been investigated in this work.

A 100-fold excess of $\mathrm{Zn}(\mathrm{II}), \mathrm{Co}(\mathrm{II}), \mathrm{Pb}(\mathrm{II}), \mathrm{Cu}(\mathrm{II}), \mathrm{Ni}(\mathrm{II}), \mathrm{Mn}(\mathrm{II}), \mathrm{Cd}(\mathrm{II}), \mathrm{Ag}(\mathrm{I})$, $\mathrm{Bi}(\mathrm{III}), \mathrm{Fe}(\mathrm{II})$ and $\mathrm{Fe}(\mathrm{III})$, a 1000-fold excess of chloride, nitrate, sulphate, fluoride, thiocyanate, bromide, phosphate, acetate, oxalate, and tartrate and had no influence on the determination of $0.05 \mathrm{mg} \mathrm{L}^{-1} \mathrm{Hg}(\mathrm{II})$.

In the presence of EDTA, cysteine, thiourea, $\mathrm{SO}_{3}{ }^{-2}, \mathrm{~S}_{2} \mathrm{O}_{3}{ }^{-2}$, and $\mathrm{SCN}^{-}$, a gradual suppression of the $\mathrm{Hg}$ signal became evident. Strong chelates probably do not release $\mathrm{Hg}$ (II) ions even in acidic solution and the bound fraction of mercury is not accessible to determination.

The results obtained are of great importance, for instance for the analysis of natural waters. The electrode is capable of measuring mercury(II) bound in labile (halide, sulphate and hydroxide) complexes.

\section{Determination of mercury(II) in natural waters}

The determination of mercury(II) was carried out in both river and sea water. Hence, the determinations were carried out in "spiked" water samples. No pretreatment of samples to remove any matrix component was carried out. The results of these analyses are given in Table 1.

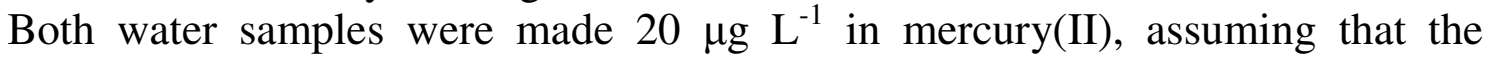
original content of these ions was negligible compared to the concentration that was spiked in. The mercury was determined by the DPASV method (standard addition technique) already described. 
Table 1. DPASV determination in natural waters containing $20 \mu \mathrm{g} \mathrm{L^{-1 }}$ mercury(II) (added).

\begin{tabular}{lcc}
\hline $\begin{array}{l}\text { Sample } \\
\text { (place) }\end{array}$ & Hg content found / $\left(\mu \mathrm{g} \mathrm{L}^{-1}\right)$ & $\begin{array}{c}\text { R.S.D. / (\%) } \\
(\mathrm{n}=7)\end{array}$
\end{tabular}

\section{River water}

Pinheiros River, Sao Paulo State 21

Tiete River, Sao Paulo State

Sea Water

Santos Beach, Sao Paulo State

The responses of the mercury peaks in both river and sea water samples were essentially of the same size. The procedure of successive additions was applied for both solutions of samples, and it was observed that linear calibration plots had practically the same slopes. These observations and results have confirmed that the DPASV method reported in this paper can be used for practical analysis. This method can also be used as a relatively simple and quick method to determine mercury(II) in polluted and industrial waste water.

\section{Conclusions}

MAT-organo-clay has been shown to be an effective solid-phase selective sorbent for $\mathrm{Hg}(\mathrm{II})$ and can also be applied in the preparation of a chemically modified carbon paste electrode.

The adsorption of $\mathrm{Hg}(\mathrm{II})$ by MAT-organo-clay is independent of the $\mathrm{pH}$ of the solution. The adsorption of the remaining metals is dependent on changes in $\mathrm{pH}$ solutions and increased when they vary from 1 to 8 . Formation of a stronger metal-to-sulphur donor atom bond accounts for the high affinity shown by 2mercapto-5-amino-1,3,4-thiadiazole (MAT) for $\mathrm{Hg}(\mathrm{II})$ on the basis of the Pearson hard-soft acid/base rule.

In the experimental conditions used, only $\mathrm{Cd}(\mathrm{II}), \mathrm{Pb}(\mathrm{II}), \mathrm{Cu}(\mathrm{II}), \mathrm{Zn}(\mathrm{II})$, and $\mathrm{Ni}(\mathrm{II})$ could be quantitatively eluted with until $1.0 \mathrm{M} \mathrm{HCl}$ or $\mathrm{HNO}_{3}$. Mercury forms a strong complex on the surface of the sorbent MAT-organo-clay, and therefore a quantitative desorption is possible by using hydrochloric or nitric acid at a high concentration (4 to $6 \mathrm{M}$ ). Quantitative elution of $\mathrm{Hg}(\mathrm{II})$ was also possible using $25 \mathrm{~mL}$ of $0.10 \mathrm{M}$ solution of cysteine in $1.0 \mathrm{M} \mathrm{HCl}$.

The carbon paste electrode modified by MAT-organo-clay shows two peaks; one cathodic peak at about $0.1 \mathrm{~V}$ and other anodic peak at $0.375 \mathrm{~V}$ scanning the potential from -0.2 to $0.8 \mathrm{~V} \quad\left(0.05 \mathrm{M} \mathrm{KNO}_{3} v s\right.$. $\left.\mathrm{Ag} / \mathrm{AgCl}\right)$. The anodic peak at $0.375 \mathrm{~V}$ presents an excellent selectivity for $\mathrm{Hg}$ (II) ions in the presence of foreign ions. The detection limit was estimated as $0.2 \mu \mathrm{g} \mathrm{L} \mathrm{L}^{-1}$. The precision of determination is satisfactory for the respective concentration level.

The carbon paste electrode modified by MAT-organo-clay proved to be a simple and selective sensor for the determination of mercury (II) in the trace 
concentration range. The considerable sensitivity and selectivity towards mercury(II) can also be useful for routine analysis.

\section{Acknowledgements}

The authors are indebted to the CNPq and FAPESP for financial support.

\section{Resumo}

Argila organo complexada de ligante-hexadeciltrimetilammonium com montmorillonite foi preparada com a finalidade de aplicação como um agente de préconcentração em um eléctrodo de pasta de carbono quimicamente modificado para determinação de mercúrio (II) em solução aquosa. A adsorção de $\mathrm{Hg}$ (II) através de complexo da argila organo modificada foi independente do $\mathrm{pH}$ da solução. A adsorção dos metais restantes $\mathrm{Cd}(\mathrm{II}), \mathrm{Pb}(\mathrm{II}), \mathrm{Cu}(\mathrm{II}), \mathrm{Zn}$ (II), e $\mathrm{Ni}$ (II) foi dependente de mudanças do $\mathrm{pH}$ das soluções e aumentou quando ele varia de 1 a 8 . O material resultante foi caracterizado por voltametria cíclica e de pulso diferencial anódico empregando um eletrodo modificado de pasta de grafite em diferentes eletrólitos de suporte. A resposta do mercúrio foi avaliada relativamente ao $\mathrm{pH}$, composição de eléctrodo, tempo de préconcentração, concentração de mercúrio, possíveis interferentes e outras variáveis.

Palavras-chave: adsorção, pré-concentração, argila, eléctrodo de pasta de carbono, voltametria.

\section{References}

1. H. Van Olphen, "An introduction to clay colloid chemistry", Wiley, $2^{\text {nd }}$ ed., New York, 1963.

2. B.K.G. Theng, "The Chemistry of Clay Organic Interactions", Wiley, New York, 1974.

3. G. Lagaly, Characterization of clays by organic compounds, Clay Miner. (1981) 1.

4. R. Bongiovanni, M. Chiarle, E. Pelizzetti, J. Dispersion Sci. Technol. 14 (1993) 255-268.

5. T.R. Jones, Clay Miner. 18 (1983) 399-410.

6. G. Lagaly, Angew. Chem. Int. Ed. Engl. 15 (1976) 575-586.

7. R.M. Barrer, Clay Clay Miner. 37 (1989) 385-395.

8. J.F. Lee, M.M. Mortland, C.T. Chiou, D.E. Kile, S.A. Boyd, Clay Clay Miner. 38 (1990) 113-120.

9. K.R. Srinivasan, H.S. Fogler, Clay Clay Miner. 38 (1990) 287-293.

10. K.R. Srinivasan, H.S. Fogler, Clay Clay Miner. 38 (1990) 277-286.

11. N.L. Dias Filho, Y. Gushikem, W.L. Polito, Anal. Chim. Acta 306 (1995) 167-172.

12. R.F. Bergstrom, D.R. Kay, J.G. Wagner, J. Chromatogr. 222 (1981) 445452.

13. M.E. Johll, D.G. Williams, D.C. Johnson, Electroanalysis 9 (1997) 13971402. 
14. P. Ugo, L. Sperni, G.A. Mazzocchin, Ann. Chim. 92 (2002) 301-311.

15. J.M. Zen, P.J. Chen, Electroanalysis 10 (1998) 12-15.

16. A. Fitch, J. Electroanal. Chem. 284 (1990) 237-244.

17. Z. Navratilova, P. Kula, Fresenius J. Anal. Chem. 367 (2000) 369-372.

18. M. Pecorari, P. Bianco, Electroanalysis 10 (1998) 181-186.

19. A. Walcarius, in: H.S. Nalwa (Ed.), Encyclopedia of Nanoscience and Nanotechnology, American Scientific Publishers, Stevenson Ranch, CA, 2 (2004) 857.

20. S.K. Dentel, A.I. Jamrah, M.G. Stapleton, Environ. Sci. Pollut. Contr. Ser. 28 (1994) 2330-2335.

21. Q.H. Zeng, A.B. Yu, D.Z. Wang, G.Q. Lu, Nanotechnology 13 (2002) 549553.

22. K.A. Carrado, Appl. Clay Sci. 17 (2000) 1-23.

23. L. Coche-Guérente, S. Cosnier, V. Desprez, P. Labbe, D. Petridis, J. Electroanal. Chem. 401 (1996) 253-256.

24. L. Coche-Guérente, V. Desprez, P. Labbe, J. Electroanal. Chem. 458 (1998) 73-76.

25. M. Morita, J. Yoshinaga, J.S. Edmonds, J. Pur. Appl. Chem. 70 (1998) 1585-1615.

26. F. Gessner, C. Schmitt, M.G. Neumann, Langmuir 10 (1994) 3749-3753.

27. N.L. Dias Filho, D.R Do Carmo "Adsorption at silica, alumina and related surfaces". Published In: Encyclopedia of Surface and Colloid Science, A.T. Hubbard, , Ed.; Marcel Dekker, Inc.: New York (2004), p 1.

28. N.L. Dias Filho, "Adsorption at Surface-Modified Silica Gels". Published In: Encyclopedia of Surface and Colloid Science, A.T. Hubbard, Ed.; Marcel Dekker, Inc.: New York, (2002) p.191.

29. N.L. Dias Filho, Polyhedron 18 (1999) 2241-2247.

30. N.L. Dias Filho, Mikrochim. Acta 130 (1999) 233-240.

31. N.L. Dias Filho, Y. Gushikem, Sep. Sci. Tech. 32 (1997) 2535-2545.

32. R.G. Pearson, J. Am. Chem. Society 85 (1963) 3533-3539.

33. I.G. Svegl, M. Kolar, B. Ogorevc, B. Pihlar, Fresenius J. Anal Chem. 361 (1998) 358-562.

34. Z. Navratilova, P. Kula, Electroanalysis 15 (2003) 837-840.

35. P. Kula, Z. Navratilova, P. Kulova, M. Kotoucek, Anal. Chim. Acta 385 (1999) 91-100.

36. J. Labuda, V. Plaskon, Anal. Chim. Acta 228 (1990) 259-263.

37. Z. Navratilova, P. Kula, Electroanalysis 4 (1992) 683-687.

38. X. Cai, K. Kalcher, W. Diewald, C. Neuhold, R.J. Magee, Fresenius J. Anal. Chem. 345 (1993) 25-31.

39. R. Agraz, M.T. Sevilla, L. Hernandez, J. Electroanal. Chem. 390 (1995) 4757.

40. P. Ugo, L. Sperni, L.M. Moretto, Application to pore-waters analysis, Electroanalysis 9 1153-1158 (1997). 